\title{
Association of butterflyfishes and stony coral tissue loss disease in the Florida Keys
}

\author{
Kara R. Noonan ${ }^{1}$ (D) Michael J. Childress ${ }^{1}$
}

Received: 3 January 2020 / Accepted: 23 July 2020/Published online: 1 August 2020

(c) The Author(s) 2020

\begin{abstract}
Since 2014, stony coral tissue loss disease (SCTLD) has rapidly spread throughout the Florida reef tract infecting and killing dozens of coral species. Previous studies have found that corallivorous fishes, such as butterflyfishes, are positively correlated with coral disease prevalence at both local and regional scales. This study investigates the association of SCTLD infection and butterflyfish abundance and behaviors on ten reefs in the middle Florida Keys. Divers conducted video surveys of reef fish abundance and disease prevalence in June 2017, 2018, and 2019; before, during, and after the outbreak of SCTLD infections. SCTLD prevalence increased from $3.2 \%$ in 2017 to $36.9 \%$ in 2018 and back to $2.7 \%$ in 2019 . Butterflyfish abundances also showed a similar pattern with a twofold increase in abundance in 2018 over abundances in 2017 and 2019. To better understand the association of individual species of butterflyfishes and diseased corals, 60 coral colonies ( 20 healthy, 20 diseased, 20 recently dead) were tagged and monitored for butterflyfish activity using both diver-based AGGRA fish counts and 1-h time-lapse videophotography collected in the summers of 2018 and 2019. All reef fishes were more abundant on corals with larger surface areas of live tissue, but only the foureye butterflyfish preferred corals with larger surface areas of
\end{abstract}

Topic Editor Morgan S. Pratchett

Electronic supplementary material The online version of this article (https://doi.org/10.1007/s00338-020-01986-8) contains supplementary material, which is available to authorized users.

Kara R. Noonan

noonan2@g.clemson.edu

1 Department of Biological Sciences, Clemson University, Clemson, SC 26934, USA diseased tissues. Estimates of association indicate that foureye butterflyfish were found significantly more on diseased corals than either healthy or recently dead corals when compared with the other species of butterflyfishes. Foureye butterflyfish were observed to feed directly on the SCTLD line of infection, while other butterflyfish were not. Furthermore, association of foureye butterflyfish with particular diseased corals decreased from 2018 to 2019 as the SCTLD infections disappeared. Our findings suggest that foureye butterflyfish recruit to and feed on SCTLD-infected corals which may influence the progression and/or transmission of this insidious coral disease.

Keywords Coral disease - Reef fish - Butterflyfish · Feeding preference

\section{Introduction}

Over the past 40 years Caribbean coral reefs have experienced a dramatic decline in live coral cover attributed largely to increases in disease (Harvell et al. 2007; Schutte et al. 2010). Warmer sea surface temperatures along with increased nutrient pollution have contributed to a proliferation of coral diseases (Harvell et al. 2002; Rosenberg and Ben-Haim 2002; Selig et al. 2006; Bruno et al. 2007) and are expected to increase in the future (Maynard et al. 2015). However, evidence suggests that mortality due to coral disease is strongly influenced by the degree of coral stress (Lesser et al. 2007; Mueller and van Woesik 2012) and holobiont composition (Bourne et al. 2009; Randall et al. 2014; Mera and Bourne 2018) leaving us much to learn about coral disease transmission.

Coral disease can be transmitted by direct contact, water-borne, or vector-borne transmission (Shore and 
Caldwell 2019), and there is growing evidence that corallivorous fishes may influence coral disease (Rice et al. 2019). Butterflyfish (family Chaetodontidae) abundance has been found to be positively correlated with coral disease prevalence at both local and regional scales (Raymundo et al. 2009). However, laboratory studies have found conflicting results regarding the impact of butterflyfish foraging on coral disease transmission, finding both evidence for (Aeby and Santavy 2006) and against (Nicolet et al. 2018) butterflyfish as disease vectors. What is clear is that some butterflyfish are attracted to and preferentially feed on diseased coral tissues which alters the progression of coral disease (Aeby 2007; Cole et al. 2009; Chong-Seng et al. 2011).

Recently, a new and previously undescribed coral disease began spreading throughout the Florida reef tract (Precht et al. 2016). Stony coral tissue loss disease (SCTLD), initially reported in 2014 near Virginia Key, has spread north and south along the Florida reef tract affecting more than 20 species of scleractinian (stony) corals (Lunz et al. 2017; Florida Keys National Marine Sanctuary 2018). The disease first appears as lesions of sloughed tissue which can rapidly spread and kill an entire coral colony in a matter of weeks (Precht et al. 2016; Muller et al. 2018; Walton et al. 2018). Characterization of the microbial communities of lesions and response to antibiotic treatments suggest that SCTLD is associated with bacterial clades commonly found associated with other coral diseases, although an exact putative agent is not yet known (Aeby et al. 2019; Meyer et al. 2019).

In the summer of 2017, we first observed the initiation of SCTLD infections on our ten reefs in the middle Keys where we were conducting reef fish surveys. Divers noted an increased frequency of butterflyfishes associated with diseased coral heads. Here, we report our observations of how changes in SCTLD prevalence are related to changes in butterflyfish abundance, distribution, and behaviors before, during, and after this coral disease outbreak. Our hypotheses were that butterflyfish abundance would increase with increasing SCTLD prevalence, butterflyfish would preferentially feed on diseased corals over healthy corals, and butterflyfish activity would influence SCTLD disease progression.

\section{Methods}

\section{Site selection and substrate census}

Our research was conducted in the middle Keys of the Florida Keys National Marine Sanctuary on ten reefs that were selected from a set of 36 reefs previously studied (Smith et al. 2018; Smith et al. 2019). These reefs, 4 inshore (10-20 $\mathrm{m}$ depth, $<4 \mathrm{~km}$ from shore) and 6 offshore (15-25 m depth, $>6 \mathrm{~km}$ offshore), were selected because of their variation in structural complexity and percent of live coral cover (Fig. 1). Each reef was censused in the early summer (June-July) in 2017, 2018, and 2019. Reef census area was defined by a permanent $50 \mathrm{~m}$ transect line that ran parallel with the primary reef axis and four perpendicular $30 \mathrm{~m}$ transects crossing the main transect at $10,20,30$, and $40 \mathrm{~m}$. Thus, the entire reef census area was $50 \times 30 \mathrm{~m}$. Substrate cover was estimated from twelve digital photographs $(50 \times 50 \mathrm{~cm})$ transect at 10 -m intervals and calculated using 25 random points per photograph generated by Coral Point Count with Excel extensions (see Smith et al. 2018 for descriptions of cover types).

\section{Reef fish abundances and behaviors}

To assess reef fish abundances across the entire reef, four videos along a $30 \times 2 \mathrm{~m}$ belt were taken on each of the secondary transects. A diver holding a PVC camera frame with two forward facing GoPro cameras attached at heights of $30 \mathrm{~cm}$ and $100 \mathrm{~cm}$ from the substrate swam the entire length of each transect at a pace such that each video was 3-4 min in length. The videos were then analyzed for reef fish species identification and abundance which were summed for all four transects. The dual cameras allowed for identification of hard to see individuals or those moving quickly across the field of view. For this study, the reef fishes were classified into five functional groups, including corallivores (five species of Chaetodon butterflyfishes), herbivores, omnivores, grunts, and predators.

In 2018, 60 coral colonies (6 per reef) either healthy $(n=20)$, actively infected with SCTLD $(n=20)$, or recently dead $(n=20)$ were marked with numbered tags, measured (max height, length, width) and photographed on five sides. They included 5 common boulder coral species (Colpophyllia natans, Montastraea cavernosa, Orbicella faveolata, Porites astreoides, Siderastrea siderea). Each photograph was analyzed using ImageJ software to estimate the percent of live, diseased, and dead coral tissue. Percent cover was converted into surface area by estimating total coral surface area using the surface area formula for a half-sphere $\left(2 \pi r^{2}\right)$ with a radius estimated as the average of (max height, length, width). In 2019, all 60 coral colonies were again photographed on five sides and reanalyzed for changes in tissue percent cover and surface area. Percent morbidity was calculated using a percent change equation between 2018 and 2019 tissue percent cover calculations. Mortality was noted when there was no longer any live or diseased tissue cover observed in 2019.

In the summers of 2018 and 2019, each coral head was monitored for fish abundance using diver-based visual AGRRA surveys. All fish observed during a five-minute 


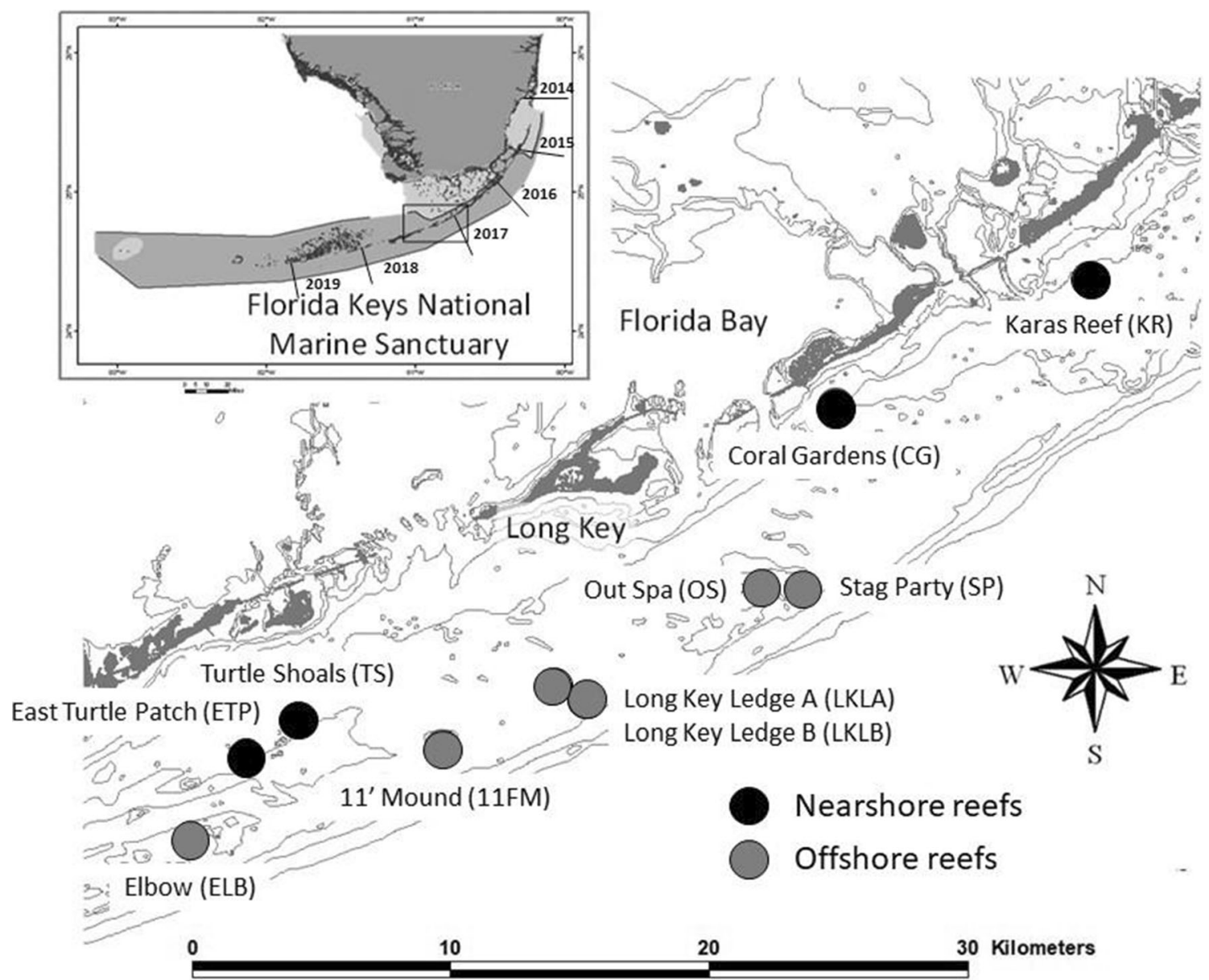

Fig. 1 Map of our ten reefs surveyed in the middle Florida Keys. Black circles indicate nearshore reefs, and gray circles indicate offshore reefs. Inset map of the Florida Keys National Marine Sanctuary indicates the spread of stony coral tissue loss disease

observation of a 5-m cylinder centered on each coral head were counted and sorted into the five functional groups described above to estimate local abundance directly related to the status of each coral head (healthy, diseased, recently dead). Abundance data were reported as numbers per five minutes.

To observe fish behaviors in the absence of divers, a single GoPro camera set for time-lapse images taken at 1-min intervals for $60 \mathrm{~min}$ was deployed $50 \mathrm{~cm}$ above the substrate and $150 \mathrm{~cm}$ from the center of the coral head. Each photograph of each coral head was scored for the presence and behaviors of all species of butterflyfishes and was categorized into five categories (absent, present but not over coral head, present over coral head but not feeding, present and feeding on coral head but not on diseased tissue, present and feeding on diseased tissue). Foureye butterflyfish (Chaetodon capistratus) were the most abundant of all the butterflyfishes and were the only species observed to feed on diseased coral tissue. The three other species of
(SCTLD) from Miami in 2014 to Key West in 2019. SCTLD infections on our reefs were just beginning in June 2017 and were gone by June 2019

butterflyfish (spotfin-C. ocellatus, banded-C. striatus, reef-C. sedentarius) were much less common and never observed to feed on diseased tissue. We summed our observations of these three species for the purpose of statistical comparison with the more common $C$. capistratus. Percent occurrence was calculated as the number of images within each category over the total number of images taken for that coral head. Since occurrence may be strongly influenced by multiple images of the same individual, we consider it a measure of coral use rather than an estimate of fish abundance.

\section{Stony coral disease census}

Disease prevalence in 2017, 2018, and 2019 was estimated from a $2 \times 50 \mathrm{~m}$ video transect taken along the main transect on each of our ten reefs. A coral was noted as "diseased" when acute to subacute tissue loss was observed with indistinct bands of pale tissue (diseased 
tissue) progressing to normal pigmentation (healthy tissue). Each video was analyzed for evidence of disease corals relative to the total number of live corals along the transect. Coral species that were surveyed include Acropora spp., Agaricia spp., Colpophyllia spp., Diploria spp., Dichocoenia spp., Montastraea spp., Orbicella spp., Porites spp., and Siderastrea spp.

\section{Statistical analyses}

Reef-wide fish counts and disease prevalence by year were analyzed by two single-factor ANOVA with Tukey's post hoc comparisons. Fish abundances and fish occurrences (square-root transformed to meet assumptions of homogeneity of variances) for each type of coral head were analyzed by single-factor ANOVA with Tukey's post hoc comparisons. Fish abundances and coral characteristics (coral species, colony length, width, height, surface area, and percent live/dead tissue) were estimated using twofactor ANOVA and Pearson's correlations with $\alpha$ values adjusted for multiple comparisons by a sequential Bonferroni correction.

\section{Results}

Across our ten sites, stony coral tissue loss disease infections in 2017 ranged from 0.0 to $8.0 \%$ with an average prevalence of $3.2 \%$. In 2018, SCTLD prevalence peaked with percentages ranging from 23.1 to $45.8 \%$ with an average prevalence of $36.9 \%$ (Table 1). Then, in 2019, disease occurrence diminished with infections ranging from 0.0 to $5.2 \%$ with an average prevalence of $2.7 \%$. Percent disease in 2018 was unrelated to region $(t=0.937$, $\mathrm{df}=2.28, p=0.3976$ ) or the amount of live hard coral cover before the outbreak $(F=0.964, \mathrm{df}=2$. 26, $p=0.3589)$. Disease prevalence was significantly higher in 2018 than either 2017 or 2019 ( $\mathrm{F}=150.9$, df $=2.26$, $p<0.0001)$.
Of the 20 diseased corals, we tagged and monitored beginning in the summer of 2018, 19 survived and showed no signs of active SCTLD infection in 2019 (Table S1). Percent morbidity ranged from $-0.5471 \%$ (increase in live tissue cover) to $100 \%$ with a mean coral morbidity of $35.1 \%$ (Table S1). However, we did not see a regional $(F=0.812, \mathrm{df}=1.27, p=0.3729)$, site $(F=1.173, \mathrm{df}=$ $9.19, \quad p=0.3455)$, or species effect on morbidity $(F=1.322, \mathrm{df}=4.24, p=0.2803)$.

Total reef fish abundance did not change over this threeyear period $(F=3.22, \mathrm{df}=2.26, p=0.0561)$. However, the abundance of corallivores (family Chaetodontidae) did show a higher abundance in $2018(F=2.92, \mathrm{df}=2.26$, $p=0.0716$ ) (Fig. 2) and was positively related to disease prevalence $(F=3.767, \mathrm{df}=1.27, p=0.0627)$, although not significantly. Total reef fish abundance around focal corals did not change from 2018 to 2019 and was unrelated to coral status (Table 2). However, foureye butterflyfish abundance was significantly higher in 2018 than in 2019, regardless of coral status $(F=11.07, \quad \mathrm{df}=1.27$, $p=0.0012)$ (Table 2).

The characteristics of coral heads with the largest impact on fish abundances were height and surface area. All reef fish were more abundant around tall coral heads and those with the greatest surface area of live tissue (Table 3). This also held true for foureye butterflyfish, but not for the other species of butterflyfishes. However, foureye butterflyfish abundance was better predicted by the surface area of diseased tissue than the surface area of live tissue. This suggests that foureye butterflyfish were attracted to tall, diseased coral heads. The species of coral had no influence on total reef fish abundance $(F=1.48$, $\mathrm{df}=4.35, p=0.1987$ ) or foureye butterflyfish abundance $(F=0.61, \mathrm{df}=4.35, p=0.6863)$.

During 2018, when corals had active SCTLD infections, the diseased and healthy corals had significantly higher occurrences of foureye butterflyfish than did dead corals $(F=3.31$, df $=1.19, p=0.0434)$ (Fig. 3a), but other species of butterflyfish did not show any difference in occurrences due to coral status $(F=0.25, \quad \mathrm{df}=1.19$,
Table 1 Percent coral cover (averaged among quarterly censuses), disease (2018 disease prevalence surveys), and preand post-disease fish abundance data for nine reef sites across the middle Florida Keys (Long Key Ledge A and B were combined for the purpose of analyses)

\begin{tabular}{llllcl}
\hline Site & Region & \%Coral cover & \%Disease & Pre-disease fish count & Post-disease fish count \\
\hline E Turtle Patch & Nearshore & 21.35 & 43.40 & 264 & 456 \\
Coral Gardens & Nearshore & 16.31 & 23.08 & 1238 & 529 \\
Karas Reef & Nearshore & 12.75 & 27.27 & NA & 572 \\
Turtle Shoals & Nearshore & 10.60 & 39.73 & 157 & 198 \\
Elbow & Offshore & 8.25 & 45.83 & 508 & 569 \\
11' Mound & Offshore & 6.63 & 41.38 & 467 & 290 \\
Stag Party & Offshore & 4.62 & 37.50 & 97 & 185 \\
LK Ledge & Offshore & 2.02 & 32.05 & 875 & 848 \\
Out Spa & Offshore & 1.96 & 41.67 & 277 & 184
\end{tabular}


Fig. 2 a Stony coral tissue loss disease infected more than $35 \%$ of all corals in June 2018 including Colpophyllia natans, Orbicella faveolata,

Montastraea cavernosa, and Siderastrea siderea. b Disease abundance (indicated in black) was significantly higher $\left(\mathrm{F}_{2,26}=150.9, P<0.0001\right)$ in 2018 than in 2017 and 2019. Butterflyfish fish abundance (Chaetodon spp.) (indicated in orange) was also higher although not significantly $\left(\mathrm{F}_{2,26}=2.92, P=0.0716\right)$ in 2018 than in 2017 and 2019 $\mathbf{a}$

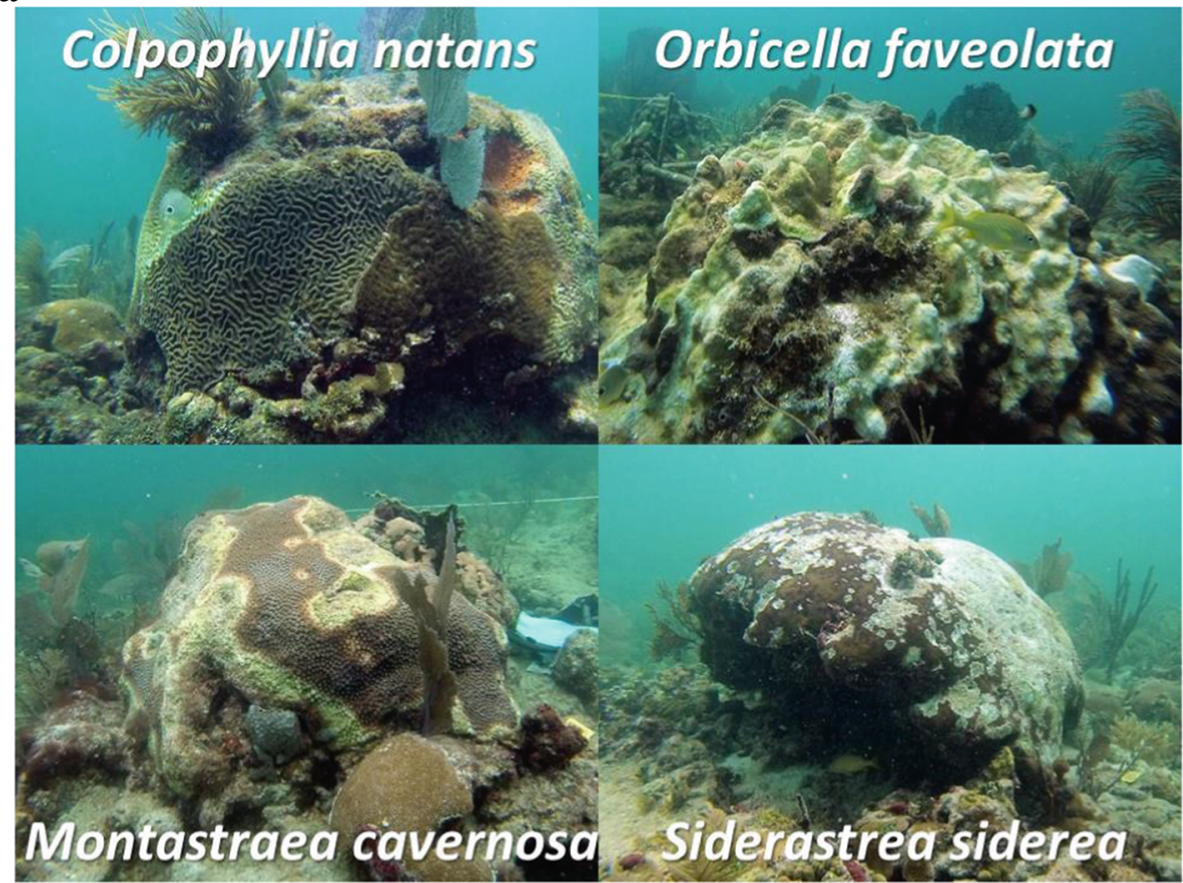

b

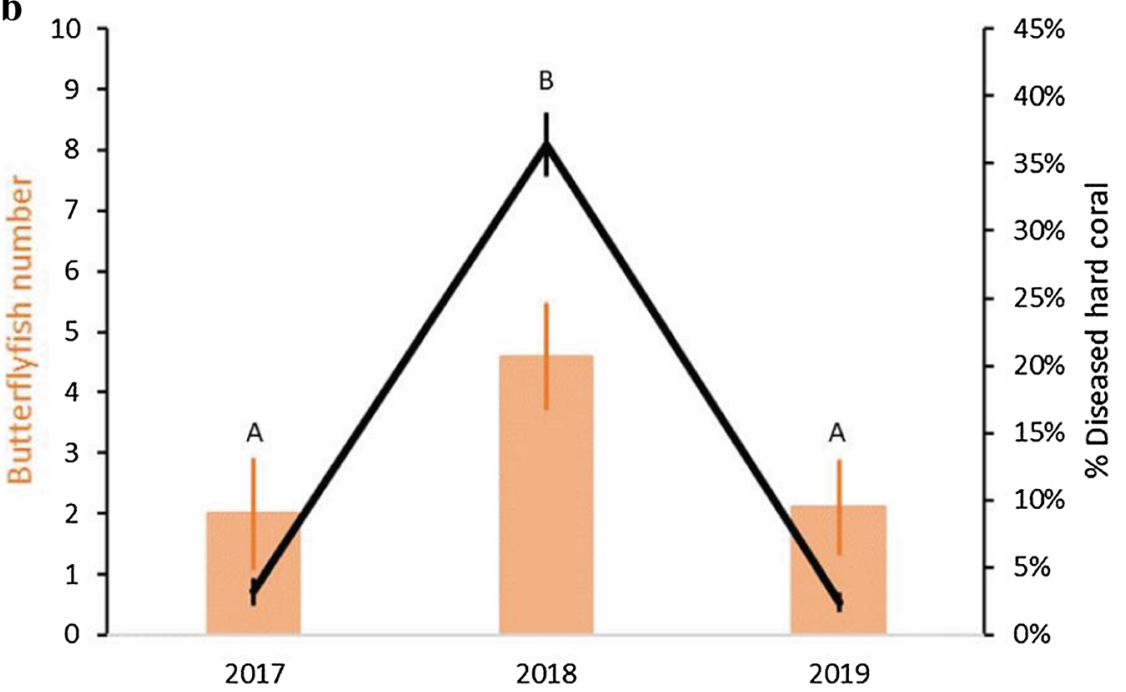

Table 2 Analysis of variance of year (2018 vs 2019) and coral status (healthy, disease/healed, dead) on fish abundance $(n=120)$

\begin{tabular}{lllrl}
\hline Fish group & Source & df & \multicolumn{1}{l}{$F$} & \multicolumn{1}{l}{$P$} \\
\hline All reef fish & Year & 1.27 & 0.23 & 0.6297 \\
& Coral status & 2.26 & 1.93 & 0.1484 \\
Other butterflyfish & Year & 1.27 & 3.32 & 0.0749 \\
& Coral status & 2.26 & 0.25 & 0.7749 \\
Foureye butterflyfish & Year & 1.27 & 11.07 & 0.0012 \\
& Coral status & 2.26 & 0.10 & 0.9015 \\
\hline
\end{tabular}

$p=0.7728$ ). This association was no longer observed when the same corals no longer had active infections of SCTLD in 2019 ( $F=0.03$, df $=1.19, p=0.9661)$ (Fig. 3b).

In 2018, during the active infections of SCTLD, foureye butterflyfish were observed feeding more often on diseased corals than on healthy corals $(F=2.67$, df $=1.19$, $p=0.0980$ ) (Fig. 4), but these differences were no longer present in 2019 after SCTLD infections had cleared $(F=0.80$, df $=1.19, p=0.4718)$. However, foureye butterflyfish feeding intensity was unrelated to the percent decrease in the surface area of healthy coral tissue between 2018 and $2019(F=0.17$, df $=1.19, p=0.9864)$. When analyzing healthy and diseased coral heads, foureye 
Table 3 Correlations of fish abundance to coral characteristics $(n=120)$

\begin{tabular}{|c|c|c|c|c|c|c|}
\hline \multirow[t]{2}{*}{ Coral characteristic } & \multicolumn{2}{|c|}{ All reef fish } & \multicolumn{2}{|c|}{ Other butterflyfish ${ }^{\mathrm{a}}$} & \multicolumn{2}{|c|}{ Foureye butterflyfish } \\
\hline & $r$ & $P$ & $r$ & $P$ & $r$ & $P$ \\
\hline Coral height & 0.227 & 0.0128* & 0.087 & 0.3437 & 0.270 & $0.0030 *$ \\
\hline Surface area (total) & 0.188 & 0.0406 & 0.032 & 0.7228 & 0.268 & $0.0032 *$ \\
\hline Surface area (live) & 0.317 & $0.0004 *$ & -0.011 & 0.9003 & 0.130 & 0.1582 \\
\hline Surface area (diseased) & 0.067 & 0.4646 & -0.046 & 0.6134 & 0.314 & $0.0005^{*}$ \\
\hline Surface area (dead) & 0.044 & 0.6279 & 0.046 & 0.6167 & 0.249 & 0.0063* \\
\hline
\end{tabular}

${ }^{a}$ Other butterflyfish includes all spotfin, banded, and reef butterflyfishes

Bold significant at $\alpha=0.05$

*Significant at global $\alpha=0.05$ by sequential Bonferroni correction butterflyfish have no relationship to percent morbidity $(F=0.51, \mathrm{df}=1.19, p=0.4795)$. Furthermore, 19 of 20 diseased corals survived their SCTLD infection regardless of the intensity of foureye butterflyfish feeding.

\section{Discussion}

Stony coral tissue loss disease reached the reefs in the middle Florida Keys in 2017, peaking in 2018, and declining significantly in 2019 (Florida Keys National Marine Sanctuary 2018). In 2018, location-specific infection rates across all available corals ranged from 23.1 percent to 45.8 percent with no correlation between percent coral cover and disease prevalence. We did not find a significant difference in coral infection rates between our inshore and offshore reefs as previously reported (Rippe et al. 2019). However, these estimates of disease prevalence may be lower than actual disease prevalence due to limitations imposed by estimating disease from video transects.

Corallivores (Chaetodontids) also showed a peak abundance in 2018, twice as high than in 2017 or 2019. This pattern was not seen in our other reef fish functional groups and thus was not a general phenomenon affecting all reef fish species. Across all censuses, there was a positive, but not significant, relationship between corallivore abundance and percent disease prevalence. A previous study found no correlation between butterflyfish abundance and the prevalence of coral disease but a positive response of corallivorous drupellids in response to disease (Raj et al. 2016). What our study suggests is that response to increasing disease prevalence is very rapid and unlikely due to increases in butterflyfish recruitment or growth rates. More likely butterflyfish are locally attracted to large diseased coral heads from surrounding areas with few diseased individuals. Whether or not butterflyfish track the movement of the disease front long distances is not yet known, but there are some studies that other corallivores, e.g., drupellids, track resources using chemical cues released by stressed corals (Stambler 2010; Tsang and Ang 2015; Kaullysing et al. 2016).

Diver-based fish surveys conducted in 2018 and 2019 found that butterflyfish were more abundant around large coral heads in 2018 than in 2019, but other reef fishes were not. This was mostly due to increases in one species of butterflyfish, $C$. capistratus. Reef fish abundance was positively correlated with coral height and area of live tissue. However, for $C$. capistratus abundance was most strongly correlated with area of diseased tissue and was unrelated to coral species. The other three species of butterflyfishes show no correlations with abundance, coral species, or size. Previous studies have found similar associations of reef fishes with large coral heads and high live tissue area due to the biological and physical structure that coral provides (Bell and Galzin 1984; Roberts and Ormond 1987; Gratwicke and Speight 2005).

Time-lapse videophotography in the absence of divers found no pattern in association for reef, spotfin, and banded butterflyfishes which showed similar frequencies during and after the disease outbreak across all coral types. However, foureye butterflyfish associated more with diseased corals than healthy or dead corals in 2018 and disappeared one year later when the same corals no longer had active SCTLD infections. While time-lapse videophotography may overestimate occurrences due to multiple observations of the same individual fish, they still corroborate our diver-based visual surveys indicating higher association by foureye butterflyfish. Foureye butterflyfish were observed feeding significantly more often on diseased corals than on healthy or dead corals with photographs indicating frequent feeding on the active disease line. These differences disappeared the following year when the infected coral heads no longer had active SCTLD. This parallels previous results where butterflyfishes were attracted to diseased corals in the field and fed on disease lesions (Aeby and Santavy 2006; Aeby 2007; Raymundo et al. 2009; Chong-Seng et al. 2011). 

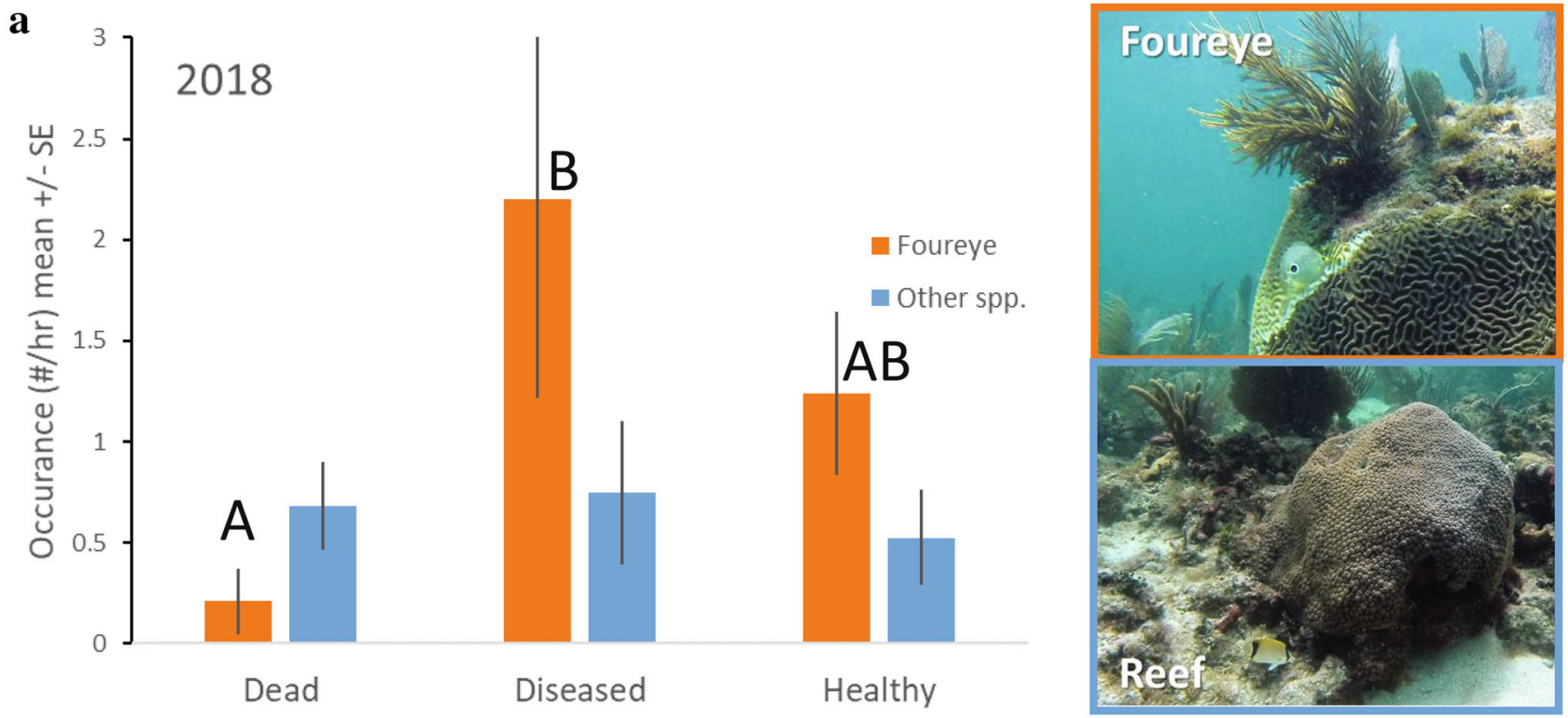

Hard coral status

b

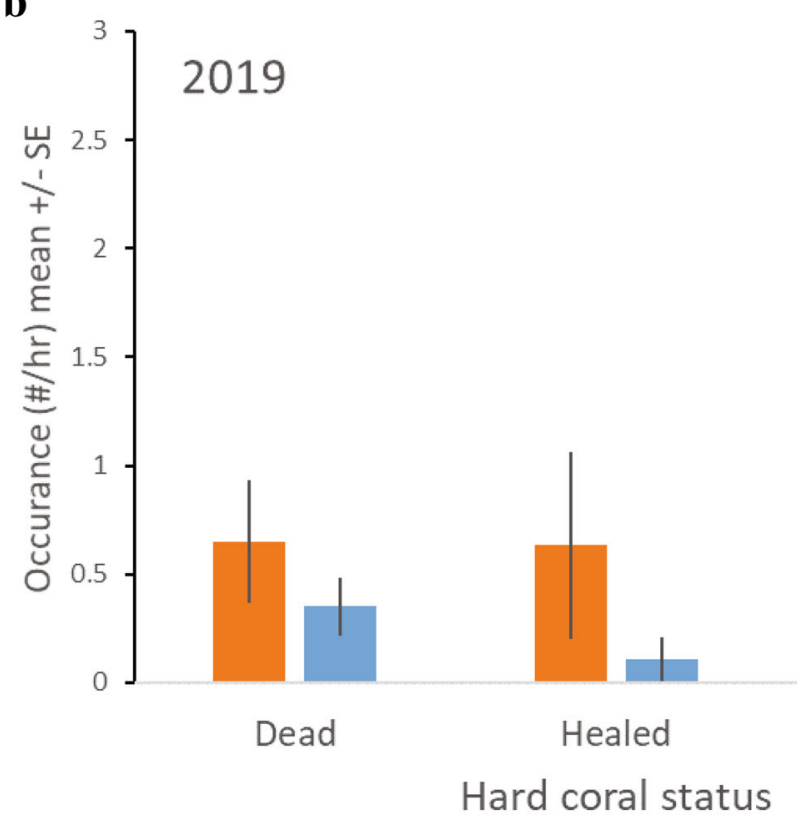

Fig. 3 Occurrence of butterflyfishes in time-lapse photographs of focal hard corals either dead, diseased, or healthy. Number of photographs per hour with foureye butterflyfish (orange) or reef, banded, spotfin butterflyfish (blue) $\mathbf{a}$ in 2018 and $\mathbf{b}$ in 2019. Note that all disease corals from 2018 were healed by 2019 and showed no

With the attraction of corallivorous fishes to sloughing coral tissue, the increase in foureye butterflyfish to diseased colonies follows previously observed trends (Aeby and Santavy 2006; Raymundo et al. 2009; Chong-Seng et al. 2011). Additionally, C. capistratus is a home-ranging (Neudecker and Lobel 1982; Gore 1983), generalist

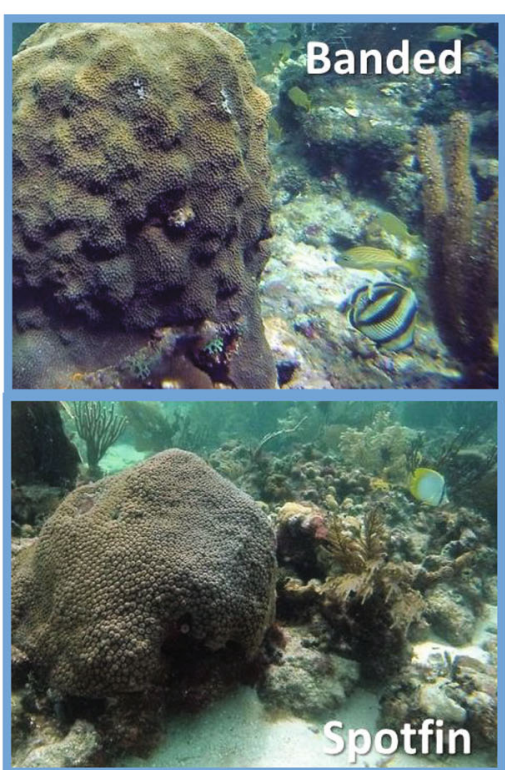

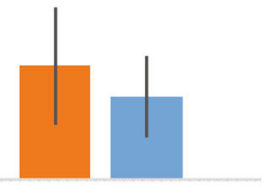

Healthy
- Foureye

nother spp.

active stony coral tissue loss disease. Occurrence of foureye butterflyfish on diseased corals in 2018 was significantly higher $(P<0.05)$ than on dead corals. Other butterflyfish occurrence was unrelated to hard coral status for both years

corallivore (Gore 1984; Cole et al. 2008; Bellwood et al. 2009), making the repeated opportunistic feedings on disease lesions expected. The lack of response of the other three species to diseased tissue may be due to differences in dietary habits. $C$. sedentarius and $C$. striatus are considered benthic invertebrate feeders (Bellwood et al. 2009), which 
Fig. 4 a Evidence of feeding on stony coral tissue loss disease by foureye butterflyfish. b Percent of occurrences where feeding was observed in 2018 and 2019 by foureye butterflyfish on dead, diseased, and healthy corals. More than $50 \%$ of all observations of foureye butterflyfish on diseased corals in 2018 indicated feeding. By 2019, these same corals no longer had active SCTLD infections and feeding was no more frequent than observed on healthy corals $\mathbf{a}$
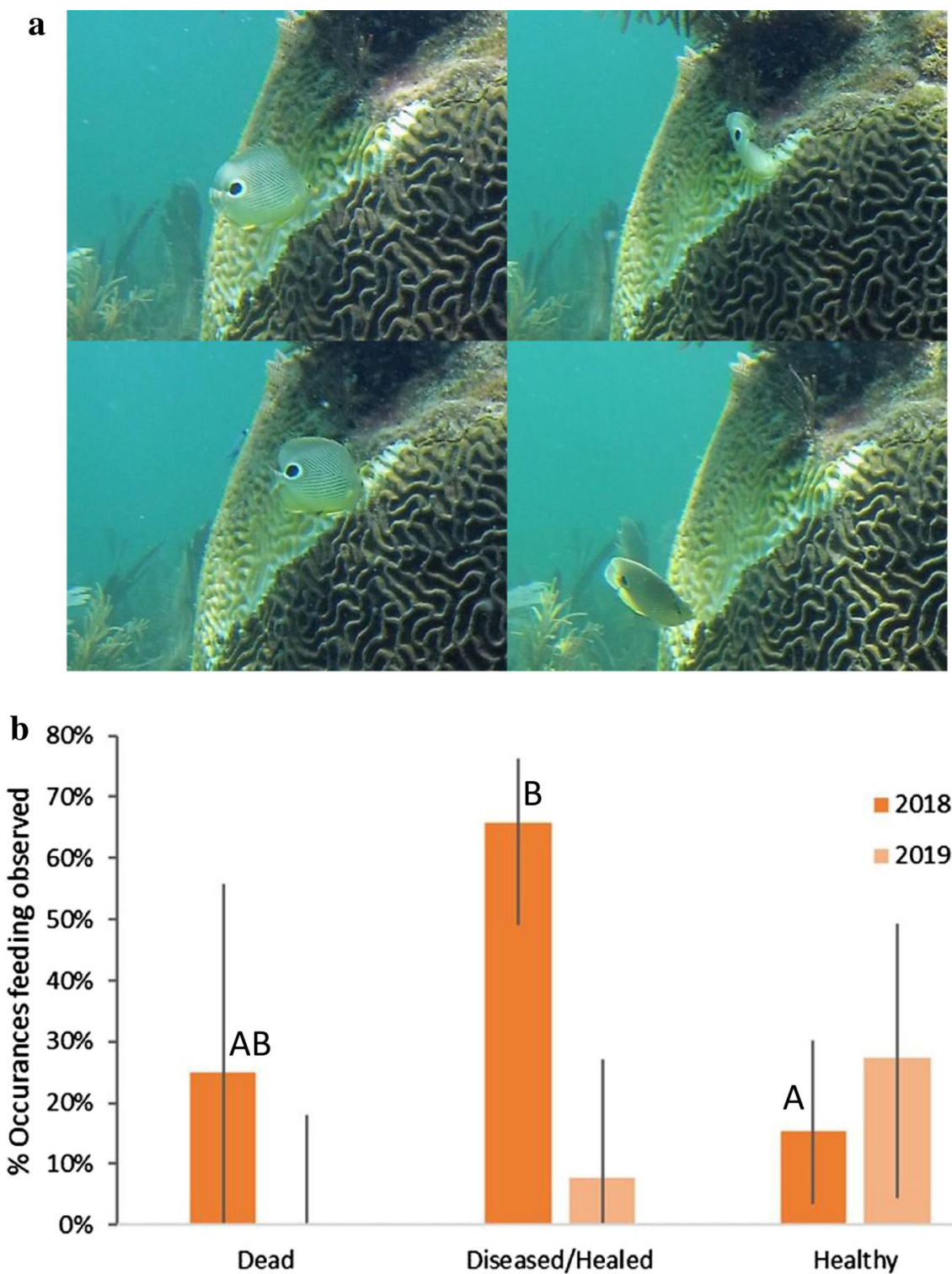

2018

2019

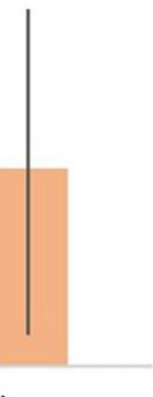

Hard coral status

explains why there was not an influx in their abundances, although spotfin butterflyfish were observed feeding on the disease lesions across our ten sites. $C$. ocellatus has similar dietary needs as $C$. capistratus, so it is unknown why they did not have a similar trend to the foureye butterflyfish.

With direct feeding on coral lesions, some studies have found that active feeding leaves corals more vulnerable to infection (Aeby and Santavy 2006; Raymundo et al. 2009), while other studies found that the active feeding and removal of infected tissue allowed corals an opportunity to recover from disease (Aeby 1983; Cole et al. 2009). We found no relationship between the abundance or frequency of occurrence of butterflyfishes and coral morbidity or mortality from SCTLD, but of our twenty infected corals, nineteen survived the infection. This may support previous findings that the butterflyfish may be halting or at least slowing the progress of disease by consuming the sloughing tissue (Aeby 1983; Cole et al. 2009). Previous work on butterflyfish transmission in black-band disease found no evidence of increased or decreased transmission (Nicolet et al. 2018).

It is unknown whether the observed increase in butterflyfish feeding influenced the rate of disease spread to uninfected corals. If butterflyfish were facilitating the spread of SCTLD, we would expect to find faster rates of new infection in areas with higher butterflyfish abundance, but if coral disease is increasing butterflyfish recruitment after initial infection, disease spread would not necessarily be related to butterflyfish abundance. More frequent observations would be needed to measure this relationship 
with appropriate butterflyfish-free corals as controls. Future research needs to investigate the potential influences that these butterflyfish may have on disease transmission, with specific focus on the surface area of live coral tissue.

This study is the first to examine the relationship between butterflyfish and stony coral tissue loss disease in the Caribbean. Given the rate of SCTLD spread and the lethality of this pathogen, understanding the role of foureye butterflyfish in its transmission should be a top priority in the efforts to protect corals and manage this disease outbreak (Shore and Caldwell 2019).

Acknowledgements This research was made possible by the Florida Keys National Marine Sanctuary (Permit \# FKNMS-2017-032 and FKNMS-2018-119). Funding for this project was provided by Clemson University's Creative Inquiry Initiative, the International Women's Fishing Association, The Explorer's Club Mamont Scholar, American Museum of Natural History Lerner-Gray Memorial Fund, and Clemson University. We thank Kylie Smith, Randi Sims, Sydney Whitaker, Isaac Ingrum, Reanna Jeanes, Riley Garvey, Rachel Radick, and Kristiaan Matthee for assistance in the field data collection. Thomas Fair, Kelsey Sox, Riley Garvey, Kristiaan Matthee, Emma Crowfoot, and Rachel Radick assisted with the data processing and analysis.

Open Access This article is licensed under a Creative Commons Attribution 4.0 International License, which permits use, sharing, adaptation, distribution and reproduction in any medium or format, as long as you give appropriate credit to the original author(s) and the source, provide a link to the Creative Commons licence, and indicate if changes were made. The images or other third party material in this article are included in the article's Creative Commons licence, unless indicated otherwise in a credit line to the material. If material is not included in the article's Creative Commons licence and your intended use is not permitted by statutory regulation or exceeds the permitted use, you will need to obtain permission directly from the copyright holder. To view a copy of this licence, visit http://creativecommons. org/licenses/by/4.0/.

\section{References}

Aeby GS (1983) The potential effect the ability of a coral intermediate host to regenerate may have had on the evolution of its association with a marine parasite. In: Proc $7^{\text {th }}$ Intl Coral Reef Symp 2: 809-815

Aeby GS, Santavy DL (2006) Factors affecting susceptibility of the coral Montastraea faveolata to black-band disease. Mar Ecol Prog Ser 318:103-110

Aeby GS (2007) Spatial and temporal patterns of infection of Porites trematodiasis on the reefs of Kaneohe Bay, Oahu, Hawaii. Bull Mar Sci 80:209-218

Aeby GS, Ushijima B, Campbell JE, Jones S, Williams GJ, Meyer JL, Hase C, Paul VJ (2019) Pathogenesis of a tissue loss disease affecting multiple species of corals along the Florida reef tract. Front Mar Sci 6:678. https://doi.org/10.3389/fmars.2019.00678

Bell JD, Galzin R (1984) Influence of live coral cover on coral-reef fish communities. Mar Ecol Prog Ser 15:265-274

Bellwood DR, Klanten S, Pratchett MS, Konow N, van Herwerden L (2009) Evolutionary history of the butterflyfishes (f: Chaetodontidae) and the rise of coral feeding fishes. J Evol Biol 23:335-349
Bourne DG, Garren M, Work TM, Rosenberg E, Smith GW, Harvell CD (2009) Microbial disease and the coral holobiont. Trends Microbiol 17:554-562

Bruno JF, Selig ER, Casey KS, Page CA, Willis BL, Harvell CD, Sweatman H, Melendy AM (2007) Thermal stress and coral cover as drivers of coral disease outbreaks. PLoS Biol 5:1220-1227

Chong-Seng KM, Cole AJ, Pratchett MS, Willis BL (2011) Selective feeding by coral reef fishes on coral lesions associated with brown band and black band disease. Coral Reefs 30:473-481

Cole AJ, Pratchett MS, Jones GP (2008) Diversity and functional importance of coral-feeding fishes on tropical coral reefs. Fish Fish 9:286-307

Cole AJ, Chong-Seng KM, Pratchett MS, Jones GP (2009) Coralfeeding fishes slow progression of black-band disease. Coral Reefs 28:965

Florida Keys National Marine Sanctuary (2018) Case definition: stony coral tissue loss disease (SCTLD). National Oceanic and Atmospheric Administration, Silver Spring

Gore MA (1983) The effect of a flexible spacing system on the social organization of a coral reef fish, Chaetodon capistratus. Behavior 85:118-145

Gore MA (1984) Factors affecting the feeding behavior of a coral reef fish, Chaetodon capistratus. Bull Mar Sci 35:211-220

Gratwicke B, Speight MR (2005) The relationship between fish species richness, abundance and habitat complexity in a range of shallow tropical marine habitats. J Fish Biol 66:650-667

Harvell CD, Mitchell CE, Ward JR, Altizer S, Dobson AP, Ostfeld RS, Samuel MD (2002) Climate warming and disease risks for terrestrial and marine biota. Science 296:2158-2162

Harvell D, Jordan-Dahlgren E, Merkel S, Rosenberg E, Raymundo L, Smith G, Weil E, Willis B (2007) Coral disease, environmental drivers, and the balance between coral and microbial associates. Oceanography 20:172-195

Kaullysing D, Gopeechund A, Mattan-Moorgawa S, Taleb-Hossenkhan N, Kulkarni B, Bhagooli R (2016) Increased density of the corallivore Drupella cornus on Acropora muricata colonies overgrown by Padina boryana. In: Proceedings of the 13th international coral reef symposium, Hawaii, USA

Lesser MP, Bythell JC, Gates RD, Johnstone RW, Hoegh-Guldberg O (2007) Are infectious diseases really killing corals? alternative interpretations of the experimental and ecological data. J Exp Mar Bio Ecol 346:36-44

Lunz K, Landsberg J, Kiryu Y, Brinkhuis V (2017) Investigation of the coral disease outbreak affecting Scleractinian corals of the Florida Reef Tract. Florida DEP, Miami, p 19

Maynard J, van Hooidonk R, Eakin CM, Puotinen M, Garren M, Williams G, Heron SF, Lamb J, Weil E, Willis B, Harvell CD (2015) Projections of climate conditions that increase coral disease susceptibility and pathogen abundance and virulence. Nat Clim Change 5:688-694

Mera H, Bourne DG (2018) Disentangling causation: complex roles of coral-associated microorganisms in disease. Environ Microbiol 20:431-449

Meyer JL, Castellanos-Gell J, Aeby GS, Häse CC, Ushijima B, Paul VJ (2019) Microbial community shifts associated with the ongoing stony coral tissue loss disease outbreak on the Florida Reef Tract. Front Microbiol. https://doi.org/10.3389/fmicb.2019. 02244

Muller EM, van Woesik R (2012) Caribbean coral diseases: primary transmission or secondary infection? Glob Chang Biol 18:3529-3535

Muller E, van Woesik R, Sartor C (2018) Spatial epidemiology modeling of the Florida coral disease outbreak. Florida Department of Environmental Protection, Tallahassee 
Neudecker S, Lobel PS (1982) Mating systems of Chaetodontid and Pomacanthid fishes at St. Croix. Zeitschrift fur Tierpsychologie 59:299-318

Nicolet KJ, Chong-Seng KM, Pratchett MS, Willis BL, Hoogenboom MO (2018) Predation scars may influence host susceptibility to pathogens: evaluating the role of corallivores as vectors of coral disease. Sci Rep 8:5258

Precht WF, Gintert BE, Robbart ML, Fura R, van Woesik R (2016) Unprecedented disease-related coral mortality in southeastern Florida. Sci Rep 6:31374

Raj KD, Aeby GS, Mathews G, Bharath MS, Rajesh S, Laju RL, Arasamuthu A, Kumar PD, Patterson Edward JK (2016) Patterns in the abundance of fish and snail corallivores associated with an outbreak of acute tissue loss disease on the reefs of Vaan Island in the Gulf of Mannar, India. In: $13^{\text {th }}$ international coral reef symposium at Honolulu, Hawaii, from $19^{\text {th }}-24^{\text {th }}$ June

Randall CJ, Jordan-Garza AG, Muller EM, van Woesik R (2014) Relationships between the history of thermal stress and the relative risk of diseases of Caribbean corals. Ecology 95:1981-1994

Raymundo LJ, Halford AR, Maypa AP, Kerr AM (2009) Functionally diverse reef-fish communities ameliorate coral disease. Proc Nat Acad Sci 106:17067-17070

Rice MM, Ezzat L, Burkepile DE (2019) Corallivory in the Anthropocene: interactive effects of anthropogenic stressors and corallivory on coral reefs. Mar Sci, Front. https://doi.org/10. 3389/fmars.2018.00525

Rippe JP, Kriefall NG, Davies SW, Castillo KD (2019) Differential disease incidence and mortality of inner and outer reef corals of the upper Florida Keys in association with a white syndrome outbreak. Bull Mar Sci 95:305-316
Roberts CM, Ormond RF (1987) Habitat complexity and coral reef fish diversity and abundance on Red Sea fringing reefs. Mar Ecol Prog Ser 41:1-8

Rosenberg E, Ben-Haim Y (2002) Microbial diseases of corals and global warming. Environ Microbiol 4:318-326

Schutte VGW, Selig ER, Bruno JF (2010) Regional spatio-temporal trends in Caribbean coral reef benthic communities. Mar Ecol Prog Ser 402:115-122

Selig ER, Harvell CD, Bruno JF, Willis BL, Page CA, Casey KS, Sweatman H (2006) Analyzing the Relationship between ocean temperature anomalies and coral disease outbreaks at broad spatial scales. Coral reefs climate change: science and management. American Geophysical Union Press, Washington, D.C., p 61

Shore A, Caldwell JM (2019) Modes of coral disease transmission: how do diseases spread between individuals and among populations? Marine Biol 166:45

Stambler N (2010) Coral symbiosis under stress. In: Seckbach J, Grube M (eds) Symbioses and Stress. Springer, Dordrecht, pp 197-224

Tsang R, Ang P (2015) Cold temperature stress and predation effects on corals: their possible roles in structuring a nonreefal coral community. Coral Reefs 34:97-108

Walton CJ, Hayes NK, Gilliam DS (2018) Impacts of a regional, multiyear, multi-species coral disease outbreak in southeast Florida. Front Mar Sci 5:323

Publisher's Note Springer Nature remains neutral with regard to jurisdictional claims in published maps and institutional affiliations. 